\title{
First case report of thyroid abscess caused by Helicobacter cinaedi presenting with thyroid storm
}

\author{
Tomohiro Takehara ${ }^{1,2}$, Tetsuo Tani ${ }^{2^{*}}$ (D) Ken Yajima ${ }^{3}$, Mako Watanabe ${ }^{4}$, Yoshihito Otsuka ${ }^{5}$ and Hidefumi Koh ${ }^{2}$
}

\begin{abstract}
Background: Helicobacter cinaedi is a microaerobic Gram-negative spiral-shaped bacterium that causes enteritis, cellulitis, and bacteremia in both immunocompromised and immunocompetent patients. While there have been increasing numbers of reported $\mathrm{H}$. cinaedi infections recently, there has been no thyroid abscess case caused by $\mathrm{H}$. cinaedi presenting with thyroid storm.

Case presentation: A 50-year-old Japanese man presented with a 9-day history of high fever associated with palpitations, dry cough, and chronic diarrhea. The patient had a history of Basedow's disease that had been treated with thiamazole in the past. During the current episode, the patient was diagnosed with thyroid storm and treated accordingly. The blood culture taken on admission was positive for $\mathrm{H}$. cinaedi. This finding was confirmed by matrix-assisted laser desorption ionization-time of flight mass spectrometry (MALDI-TOFMS). A systemic computed tomography (CT) scan revealed a thyroid abscess as the site of infection and cause of the bacteremia. The 16S rRNA gene sequencing identified the pathogen of thyroid abscess as $\mathrm{H}$. cinaedi. Clinical symptoms and laboratory data normalized on admission day 7 after treatment with both effective antibiotics and antithyroid drugs.

Conclusions: The case study described a patient with a history of Basedow's disease that presented with a thyroid abscess caused by $\mathrm{H}$. cinaedi with symptoms similar to those of thyroid storm. While this bacterium has been implicated in other infections, we believe this is the first time the bacteria has been documented to have caused a thyroid abscess.
\end{abstract}

Keywords: Helicobacter cinaedi, Thyroid abscess, Basedow's disease, Thyroid storm

\section{Background}

Helicobacter cinaedi is a microaerobic Gram-negative spiral-shaped bacterium first documented as a cause of gastrointestinal symptoms in patients with human immunodeficiency virus (HIV) in 1984 [1]. Soon after its discovery, $H$. cinaedi was mostly found in HIV patients presenting with gastrointestinal disease, but was subsequently detected in other immunosuppressive conditions such as hematological disease, cancer, chronic liver disease, asplenia, and patients being treated with immunosuppressive drugs [2]. In several recent reports, $H$. cinaedi infection has also been identified in immunocompetent

\footnotetext{
* Correspondence: tetsuo19840324@yahoo.co.jp

Division of Pulmonary Medicine, Department of Internal Medicine,

Federation of National Public Service Personnel Mutual Aid Associations,

Tachikawa Hospital, 4-2-22 Nishikicho, Tachikawa, Tokyo 190-8531, Japan

Full list of author information is available at the end of the article
}

people [3, 4]. $H$. cinaedi is known to be the causative organism of bacteremia [5], cellulitis [6], enteritis [7], arthritis [8], meningitis [9], infective endocarditis [10], vertebral osteomyelitis [11], and kidney cyst infection [12]. H. cinaedi is a slow-growing bacterium in culture and difficult to diagnose [13]. Additionally, the standard antibiotic therapy for $H$. cinaedi infection has not yet been determined. Patients may suffer reoccurring $H$. cinaedi infection if the treatment time is not long enough [14].

It is extremely rare for a thyroid abscess to be caused solely by a bacterial infection because the thyroid gland anatomically and physiologically forms a protective barrier to infection [15]. Previous reports state that thyroid abscesses are usually caused by anatomical abnormalities like pyriform sinus fistula [16] or due to ingestion a foreign body that subsequently damages the thyroid, such as a migratory fish bone [17]. The causative pathogens

(c) The Author(s). 2019 Open Access This article is distributed under the terms of the Creative Commons Attribution 4.0 International License (http://creativecommons.org/licenses/by/4.0/), which permits unrestricted use, distribution, and 
in these cases are mainly Gram-positive organisms such as Staphylococcus and Streptococcus species [18].

This case study presents the first known case of a thyroid abscess caused by $H$. cinaedi in an immunocompetent patient with symptoms similar to thyroid storm.

\section{Case presentation}

A 50-year-old Japanese man presented to our hospital with a 9-day history of a high fever associated with palpitations and dry cough. He denied a sore throat, cervical pain, dyspnea, and stomachache. He had a 7-year history of Basedow's disease previously treated with thiamazole, but had discontinued the medication more than one year before the current admission. The patient had chronic mild diarrhea and had lost $20 \mathrm{~kg}$ in the preceding 6 months. Additional past medical history included childhood asthma. The only regular medication taken by the patient was the discontinued thiamazole. The patient had smoked 1 pack of cigarettes a day for 30 years, but drank no alcohol. The only sexual contact was with his wife. He denied any sick contacts or recent travel.

On physical examination, the patient appeared anxious and was febrile (temperature, $39.1^{\circ} \mathrm{C}$ ). His blood pressure was 129/77 mmHg, pulse 131 beats per minute, and respiratory rate 34 breaths per minute with an oxygen saturation of $97 \%$ on room air. He was alert and had an exophthalmos. On palpation, the thyroid gland was soft and diffusely enlarged, but non-tender with no skin redness or warmth (Fig. 1). His cardiovascular examination revealed tachycardia and the lungs were clear to auscultation. His bowel sounds were hyperactive, but the abdomen



was non-tender. Neurological examination yielded completely normal findings and no skin rash was present.

Initial laboratory results showed leukocytosis $(11,360$ white blood cells (WBC) $/ \mu \mathrm{L}$ with neutrophils at $78.6 \%$ ) and hyperthyroidism with TSH $<0.021 \mu \mathrm{IU} / \mathrm{mL}, \mathrm{F}-\mathrm{T} 3>$ $30.00 \mathrm{pg} / \mathrm{mL}, \mathrm{F}-\mathrm{T} 4$ at $8.88 \mathrm{ng} / \mathrm{mL}$, and TSH receptor antibody $42.2 \mathrm{IU} / \mathrm{L}$. Other significant laboratory findings were C-reactive protein (CRP) at $5.07 \mathrm{mg} / \mathrm{dl}$, and glycated hemoglobin (HbA1c) at 5.6\%. Test results for HBs antigen, HBs antibody, HCV antibody, and HIV antibody were not remarkable. There were normal findings on the urinalysis and chest X-ray findings. Echocardiography showed normal ejection fraction (64\%) and no signs of valve vegetation.

After admission, the patient was initially diagnosed with thyroid storm (due to tachycardia, diarrhea, and thyroid hormone levels) and treatment with thiamazole ( $30 \mathrm{mg} /$ day), hydrocortisone $(200 \mathrm{mg} /$ day), and potassium iodide $(100 \mathrm{mg} /$ day $)$ was initiated. Due to the high fever and dry cough, he was also treated with ceftriaxone (CTRX) (2g/day). Sputum and blood cultures were taken to determine the causative agent. After $80 \mathrm{~h}$ post admission, Gram-negative bacteria were cultured in two sets of aerobic blood culture bottles. Blood cultures were processed through the BACTEC FX system (Becton Dickinson, Sparks, Maryland). Gram staining of the cultured bacteria showed a spiral and curved shape, which was morphologically compatible with $H$. cinaedi (Fig. 2). This identification was confirmed via matrix-assisted laser desorption ionization-time of flight mass spectrometry (MALDI-TOFMS). MALDI-TOFMS analysis was performed, using a MALDI Biotyper system (Bruker Daltonics, Bremen, Germany) as previously described [19]. The pathogen was identified as $H$. cinaedi with a score of 2.0. The score of $\geq 2.0$ was useful for identification to the species level. The sputum culture yielded no positive findings, including for acid-fast bacteria.

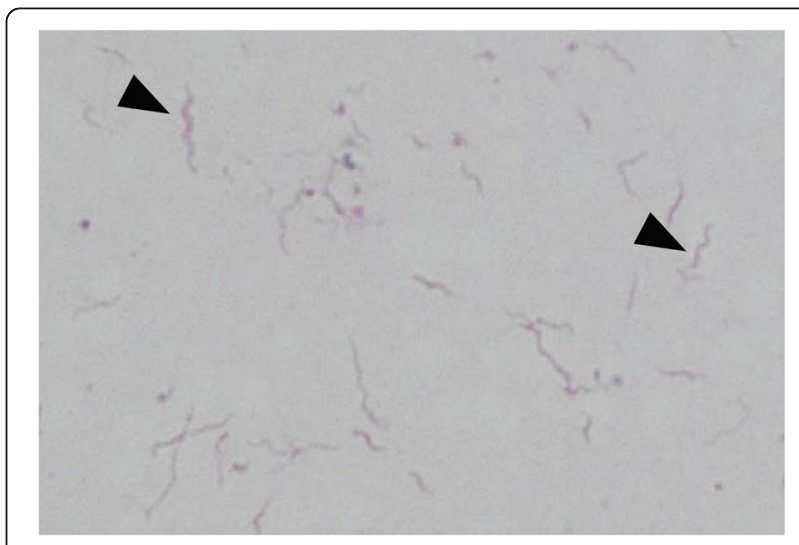

Fig. 2 The Gram staining (original magnification $\times 1000$ ) of blood culture. There were Gram-negative spiral and curved bacteria (black arrowhead) 
To determine the origin of the infection, we performed a whole-body contrast-enhanced CT scan and found a thyroid nodule in the right lobe (Fig. 3a). There was no other infection site identified and the size of the spleen was normal. The thyroid gland ultrasound examination showed high speed velocity in the thyroid vessels and a right lobe thyroid nodule that measured approximately $36 \times 38 \times 28 \mathrm{~mm}$ (Fig. 4). When the patient was first diagnosed with Basedow's disease 7 years previously, there was no thyroid cyst present at that time. Fine-needle aspiration biopsy revealed that the thyroid nodule contained a reddish purulent liquid with a total volume of $6 \mathrm{ml}$ (Fig. 5). Laboratory examination of the aspirated liquid revealed a total cell count of $40,000 / \mu \mathrm{L}$ with polymorphonuclear leukocytes $14,667 / \mu \mathrm{L}$, lactate dehydrogenase $16,990 \mathrm{IU} / \mathrm{L}$, protein $3.5 \mathrm{~g} / \mathrm{dL}, \mathrm{pH}$ level of 7.039 , and glucose at $31 \mathrm{mg} / \mathrm{dl}$. These findings were compatible with a diagnosis of bacterial abscess. Likely due to CTRX administration upon admission, the Gram staining and culture of the specimens yielded no bacteria including acid-fast bacteria. Hence, we analyzed the liquid via broad-range $16 \mathrm{~S}$ rRNA gene polymerase chain reaction (PCR). Nucleic acids were extracted from the liquid using a QIAamp DNA Mini Kit (Qiagen, Limburg, Netherlands) as specified by the manufacturer, and fragments of the 16S rRNA gene were PCR-amplified using universal primers. The PCR products were sequenced using an Applied Biosystems 3130xl Genetic Analyzer (Thermo Fisher Scientific, Waltham, MA, USA) with the primers used for PCR amplification. The amplified $16 \mathrm{~S}$ rRNA sequence had the highest similarity to that of $H$. cinaedi [1441/1451 (99.31\%) base pair matches in BLAST, and 1436/1438 (99.51\%) base pair matches in Ez Taxon]. An additional file showed the result of the sequence in more detail [see Additional file 1]. The patient was then diagnosed with $H$. cinaedi bacteremia and thyroid abscess complicated by uncontrolled Basedow's disease.

After the determination of the causative pathogen, we changed antibiotics from CTRX to amoxicillin (AMPC) at $1.5 \mathrm{~g} /$ day. On admission day 4, the patient's high fever, tachycardia, and diarrhea were improved. The serum levels of CRP and thyroid hormone were also improving. Blood cultures were drawn again on admission day 10 and were then negative. A laryngeal endoscopy was performed to check for any anatomical abnormalities and the findings were normal. The patient was discharged on admission day 24 , and continued taking thiamazole $(30 \mathrm{mg} /$ day) and AMPC $(1.5 \mathrm{~g} /$ day).

On follow-up in the outpatient clinic, the patient received both a thyroid echography and contrast-enhanced CT scan several times to ensure the abscess had not relapsed (Fig. 3b). The AMPC was taken for 6 months in total. There were no subsequent recurrences of thyrotoxic symptoms or infection. After the inflammation and infection were cleared, esophagography detected no anatomic anomalies such as pyriform sinus fistula. Seven months after diagnosis, the patient underwent a total thyroidectomy for the treatment of Basedow's disease and to prevent recurrence of a thyroid abscess. The histopathology of the removed thyroid showed it was benign and did not have signs of the thyroid abscess. The patient is now taking levothyroxine for the management of hypothyroidism.

\section{Discussion and conclusions}

To the best of our knowledge, this is the first documented case of thyroid abscess caused by $H$. cinaedi presenting with symptoms similar to thyroid storm. The patient's clinical symptoms and thyroid hormone values were suggestive of thyroid storm, but could also signify a systemic inflammatory response syndrome induced by bacteremia. Steroid administration for treatment of thyroid storm masks fever and suppresses immunity, which can worsen infectious disease processes. Consequently health care providers should be cognizant of the possibility of bacterial infections in febrile patients with Basedow's disease and the need for blood cultures to definitively diagnose the condition. In this case study, the patient was considered immunocompetent. He would not have been expected to be at risk for $H$. cinaedi infection. Araoka et al. reported that the rate of positive stool cultures was about $50 \%$ in cases of $H$. cinaedi bacteremia, suggesting the possibility of bacterial translocation [20]. We initially thought the patient's diarrhea was due to thyroid storm, so failed to obtain a stool culture. We speculate that the $H$. cinaedi bacteremia was caused by chronic diarrhea due to uncontrolled Basedow's disease, which

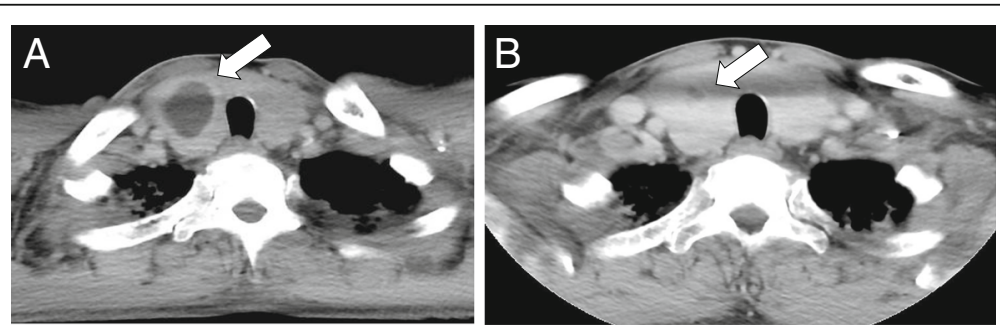

Fig. 3 The thyroid gland findings on computed tomography (CT) scan. a. The systemic contact-enhanced CT scan on admission day 4 showing enlarged thyroid gland and low-density area in the right lobe (white arrow). b. The systemic contact-enhanced CT scan of the thyroid gland 5 months after admission showing the small remains of the thyroid abscess in the right lobe (white arrow) 


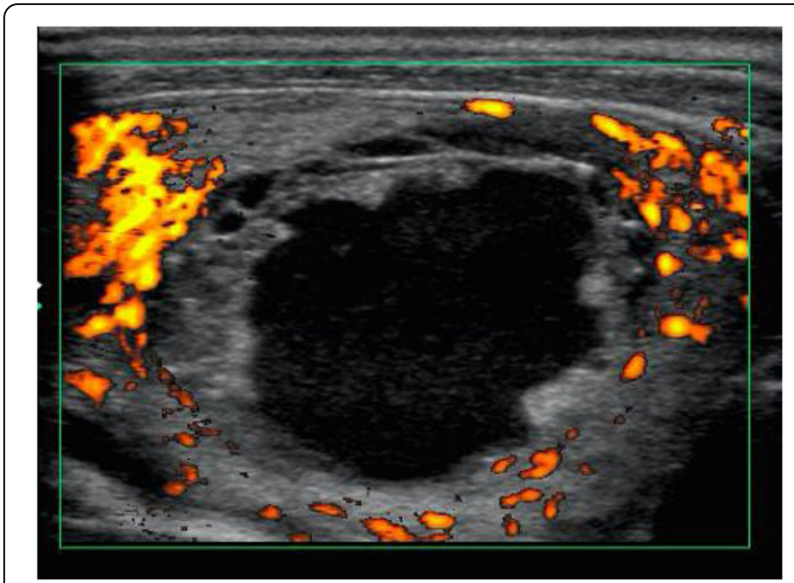

Fig. 4 Ultrasound examination of the thyroid gland on admission day 4 showing a thyroid nodule in the right lobe surrounded by enriched thyroid vessels

triggered intestinal bacterial translocation. $H$. cinaedi bacteremia subsequently led to the thyroid abscess.

Acute suppurative thyroiditis (AST) or thyroid abscess is a rare infectious disease, representing less than $1 \%$ of all thyroid diseases because the thyroid gland has rich vascularity, a protective capsule, and high iodine content [21]. AST and thyroid abscess usually present with an acutely enlarging neck mass. The main causes are pyriform sinus fistula related to anomalies of the third and fourth branchial pouches [22], following neoplastic

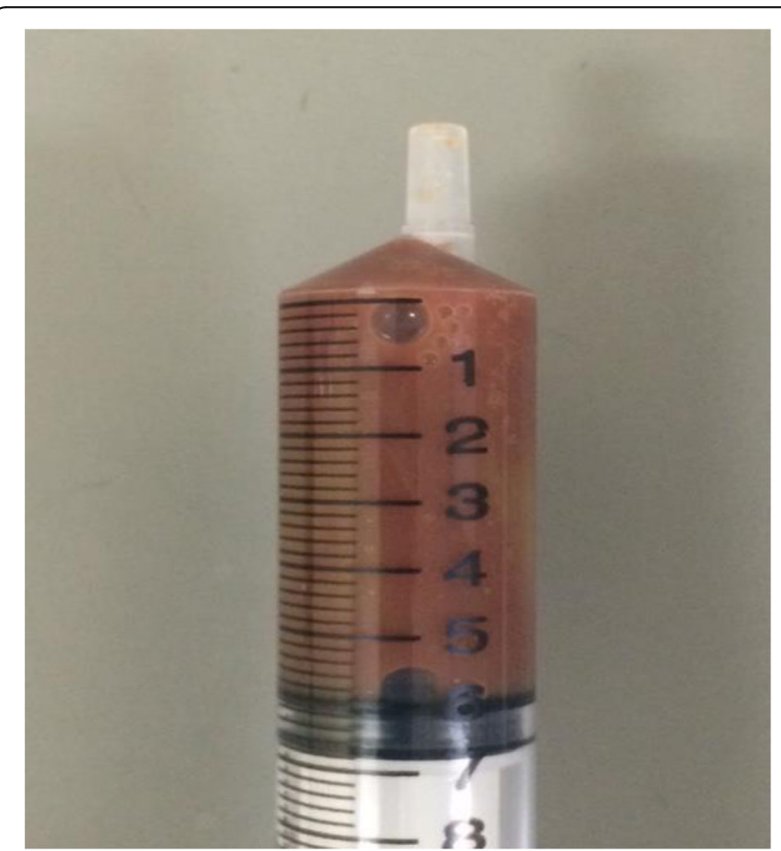

Fig. 5 The reddish purulent liquid drained from the thyroid nodule in the right lobe thyroid nodule [21, 22], Hashimoto thyroiditis [23], and penetration of the thyroid gland by foreign bodies such as fish bones [17]. Underlying comorbidities including tuberculosis, diabetes mellitus, and HIV infection appear to increase the risk of developing thyroid abscess. Staphylococcus and Streptococcus species are the major causative organisms of AST [18], and Salmonella [24], Mycobacterium tuberculosis [25] have also been reported in rare cases.

Additionally, this is also the first case of thyroid abscess caused by $H$. cinaedi in a Basedow's disease patient with normal neck anatomy. At the time of diagnosis of Basedow's disease, thyroid gland echography revealed no thyroid cyst or nodule. The clinical manifestations of this case are extremely rare as the patient had no pain or outward sign of infection at the thyroid or in surrounding tissue. This implies that the thyroid abscess was caused by $H$. cinaedi bacteremia, not by bacterial entry from the outer skin. The broad-range PCR method is robust especially for detecting and identifying the causative pathogens of culture-negative infections such as this case [26].

As noted, the patient was not adhering to the recommended medication regime to control the Basedow's disease at the time of admission. Additionally, since thyroid abscess can be a risk factor for the recurrence of thyroid storm, we considered him an appropriate candidate for thyroidectomy. Prior to surgery, the thyroid hormone levels had to be controlled in order to downsize the thyroid gland to minimize intraoperative blood loss. For this reason, the duration of antibiotic administration was much longer than that of a previously reported case [27]. There was no evidence of thyroid abscess at the surgical site, so the duration of antibiotic administration appeared to be sufficient. We showed that $H$. cinaedi-induced thyroid abscess could be cured by AMPC combined with drainage of the abscess and control of thyroid hormone levels. There are currently no recommended guidelines on the choice of antibiotic therapy and drug susceptibility testing for $H$. cinaedi. The agar dilution method is generally used for these bacterial strains; however, we did not have the results and treated the case by AMPC according to past reports [6, 28].

In conclusion, this case is quite meaningful in its clinical manifestation, causative pathogen, infection site, and treatment. Further reports are necessary to clarify the association between thyroid abscess and $H$. cinaedi bacteremia.

\section{Additional file}

Additional file 1: The $16 \mathrm{~S}$ rRNA sequence of the isolated bacteria (DOCX $12 \mathrm{~kb}$ ) 


\section{Abbreviations}

AMPC: Amoxicillin; AST: Acute suppurative thyroiditis; CRP: C-reactive protein; $\mathrm{CT}$ : Computed tomography; CTRX: Ceftriaxone; F-T3: Free triiodothyronine; FT4: Free thyroxine; $H$. cinaedi: Helicobacter cinaedi; HbA1c: glycated hemoglobin; HBs: Hepatitis B virus; HCV: Hepatitis C virus; HIV: Human immunodeficiency virus; PCR: Polymerase chain reaction; TSH: Thyroid stimulating hormone

\section{Acknowledgements}

We thank Sayoko Nagai and Yoshio Shirai at Department of Microbiological Laboratory, Tachikawa Hospital, and Kohei Hashimoto at Department of Clinical Laboratory, Kameda Medical Center for assistance in microbiological analysis. We also especially thank otolaryngologist Shintaro Nakamura at Tachikawa Hospital for helping diagnosis and Akifumi Suzuki at Ito Hospital for performing thyroidectomy.

\section{Funding}

Not applicable.

\section{Availability of data and materials}

Not applicable.

\section{Authors' contributions}

TT1 and TT2 drafted the manuscript and were responsible for the clinical care of the patients. MW and $\mathrm{YO}$ assessed the microbiological analysis. KY and HK supervised the conduct of the study and made critical revisions to the paper for important intellectual content. All authors read and approved the final manuscript.

\section{Ethics approval and consent to participate}

Not applicable.

\section{Consent for publication}

Written informed consent was obtained from the patient for publication of this case report and images.

\section{Competing interests}

The authors declare that they have no competing interests.

\section{Publisher's Note}

Springer Nature remains neutral with regard to jurisdictional claims in published maps and institutional affiliations.

\section{Author details}

'Division of Pulmonary Medicine, Department of Medicine, Keio University School of Medicine, Tokyo, Japan. ${ }^{2}$ Division of Pulmonary Medicine, Department of Internal Medicine, Federation of National Public Service Personnel Mutual Aid Associations, Tachikawa Hospital, 4-2-22 Nishikicho, Tachikawa, Tokyo 190-8531, Japan. ${ }^{3}$ Division of Diabetes, Endocrinology and Metabolism, Department of Internal Medicine, Federation of National Public Service Personnel Mutual Aid Associations, Tachikawa Hospital, Tokyo, Japan. ${ }^{4}$ Department of Microbiological Laboratory, Federation of National Public Service Personnel Mutual Aid Associations, Tachikawa Hospital, Tokyo, Japan. ${ }^{5}$ Department of Clinical Laboratory, Kameda Medical Center, Chiba, Japan.

Received: 5 October 2018 Accepted: 12 February 2019

Published online: 15 February 2019

\section{References}

1. Totten PA, Fennell CL, Tenover FC, Wezenberg JM, Perine PL, Stamm WE, et al. Campylobacter cinaedi (sp. nov.) and campylobacter fennelliae (sp. nov.): two new campylobacter species associated with enteric disease in homosexual men. J Infect Dis. 1985;151(1):131-9.

2. Murakami H, Goto M, Ono E, Sawabe E, Iwata M, Okuzumi K, et al. Isolation of helicobacter cinaedi from blood of an immunocompromised patient in Japan. J Infect Chemother. 2003:9(4):344-7.

3. Kitamura T, Kawamura Y, Ohkusu K, Masaki T, Iwashita H, Sawa T, et al. Helicobacter cinaedi cellulitis and bacteremia in immunocompetent hosts after orthopedic surgery. J Clin Microbiol. 2007;45(1):31-8.
4. Uwamino Y, Muranaka K, Hase R, Otsuka Y, Hosokawa N. Clinical features of community-acquired helicobacter cinaedi bacteremia. Helicobacter. 2016; 21(1):24-8.

5. Imafuku A, Araoka H, Tanaka K, Marui Y, Sawa N, Ubara Y, et al. Helicobacter cinaedi bacteremia in four renal transplant patients: clinical features and an important suggestion regarding the route of infection. Transpl Infect Dis. 2016;18(1):132-6.

6. Kiehlbauch JA, Tauxe RV, Baker CN, Wachsmuth IK. Helicobacter cinaediassociated bacteremia and cellulitis in immunocompromised patients. Ann Intern Med. 1994;121(2):90-3.

7. Quinn TC, Goodell SE, Fennell C, Wang SP, Schuffler MD, Holmes KK, et al. Infections with campylobacter jejuni and campylobacter-like organisms in homosexual men. Ann Intern Med. 1984;101(2):187-92.

8. Lasry S, Simon J, Marais A, Pouchot J, Vinceneux P, Boussougant Y. Helicobacter cinaedi septic arthritis and bacteremia in an immunocompetent patient. Clin Infect Dis. 2000;31(1):201-2.

9. Sugiyama A, Mori M, Ishiwada N, Himuro K, Kuwabara S. First adult case of helicobacter cinaedi meningitis. J Neurol Sci. 2014;336(1-2):263-4.

10. Bartels H, Goldenberger D, Reuthebuch O, Vosbeck J, Weisser M, Frei R, et al. First case of infective endocarditis caused by helicobacter cinaedi. BMC Infect Dis. 2014;14:586

11. Hase R, Hirooka T, Itabashi T, Endo Y, Otsuka Y. Vertebral osteomyelitis caused by helicobacter cinaedi identified using broad-range polymerase chain reaction with sequencing of the biopsied specimen. Intern Med. 2018;57(10):1475-7.

12. Ito K, Yamamoto T, Nishio H, Sawaya A, Murakami M, Kitagawa A, et al. Bacteremic kidney cyst infection caused by helicobacter cinaedi. CEN Case Rep. 2016;5(2):121-4.

13. Araoka H, Baba M, Kimura M, Abe M, Inagawa H, Yoneyama A. Clinical characteristics of bacteremia caused by helicobacter cinaedi and time required for blood cultures to become positive. J Clin Microbiol. 2014;52(5):1519-22.

14. Uckay I, Garbino J, Dietrich PY, Ninet B, Rohner P, Jacomo V. Recurrent bacteremia with helicobacter cinaedi: case report and review of the literature. BMC Infect Dis. 2006;6:86

15. Herndon MD, Christie DB, Ayoub MM, Duggan AD. Thyroid abscess: case report and review of the literature. Am Surg. 2007;73(7):725-8.

16. Yolmo D, Madana J, Kalaiarasi R, Gopalakrishnan S, Kiruba Shankar M, Krishnapriya S. Retrospective case review of pyriform sinus fistulae of third branchial arch origin commonly presenting as acute suppurative thyroiditis in children. J Laryngol Otol. 2012;126(7):737-42.

17. Chen CY, Peng JP. Esophageal fish bone migration induced thyroid abscess: case report and review of the literature. Am J Otolaryngol. 2011;32(3):253-5.

18. Yedla N, Pirela D, Manzano A, Tuda C, Lo Presti S. Thyroid abscess: challenges in diagnosis and management. J Investig Med High Impact Case Rep. 2018;6:2324709618778709.

19. Taniguchi T, Sekiya A, Higa M, Saeki Y, Umeki K, Okayama A, et al Rapid identification and subtyping of helicobacter cinaedi strains by intact-cell mass spectrometry profiling with the use of matrix-assisted laser desorption ionization-time of flight mass spectrometry. J Clin Microbiol. 2014:52(1):95-102.

20. Araoka H, Baba M, Okada C, Kimura M, Sato T, Yatomi Y, et al. First evidence of bacterial translocation from the intestinal tract as a route of helicobacter cinaedi bacteremia. Helicobacter. 2018;23(1).

21. Kim JM, Kim JY, Jung EJ, Song EJ, Kim DC, Jeong CY, et al. Cooccurrence of metastatic papillary thyroid carcinoma and Salmonella induced neck abscess in a cervical lymph node. Case Rep Med. 2017:2017:5670429.

22. Kalladi Puthanpurayil S, Francis GL, Kraft AO, Prasad U, Petersson RS. Papillary thyroid carcinoma presenting as acute suppurative thyroiditis: a case report and review of the literature. Int J Pediatr Otorhinolaryngol. 2018;105:12-5.

23. Chinnakkulam Kandhasamy S, Kumar S, Sangwan A, Sahani N, Gunasekaran G, Kumar Meena S, et al. Unusual presentation of tuberculous thyroid abscess in a background of Hashimoto's thyroiditis in a chronic hepatitis B carrier. Case Rep Surg. 2016;2016:5295236.

24. Dai MS, Chang H, Peng MY, Ho CL, Chao TY. Suppurative salmonella thyroiditis in a patient with chronic lymphocytic leukemia. Ann Hematol. 2003;82(10):646-8

25. Dv K, Gunasekaran K, Mishra AK, lyyadurai R. Disseminated tuberculosis presenting as cold abscess of the thyroid gland-a case report. Oxf Med Case Reports. 2017;2017(9):omx049.

26. Stavnsbjerg C, Frimodt-Moller N, Moser C, Bjarnsholt T. Comparison of two commercial broad-range PCR and sequencing assays for identification of bacteria in culture-negative clinical samples. BMC Infect Dis. 2017;17(1):233. 
27. Araoka H, Baba M, Okada C, Kimura M, Sato T, Yatomi Y, et al. Risk factors for recurrent helicobacter cinaedi bacteremia and the efficacy of selective digestive decontamination with kanamycin to prevent recurrence. Clin Infect Dis. 2018;67(4):573-8

28. Kuijper EJ, Stevens S, Imamura T, De Wever B, Claas EC. Genotypic identification of erythromycin-resistant campylobacter isolates as

helicobacter species and analysis of resistance mechanism. J Clin Microbiol. 2003:41(8):3732-6

Ready to submit your research? Choose BMC and benefit from:

- fast, convenient online submission

- thorough peer review by experienced researchers in your field

- rapid publication on acceptance

- support for research data, including large and complex data types

- gold Open Access which fosters wider collaboration and increased citations

- maximum visibility for your research: over $100 \mathrm{M}$ website views per year

At $\mathrm{BMC}$, research is always in progress.

Learn more biomedcentral.com/submissions 